\title{
Exploring the Relationship between Government R \& D Expenditures and Economic Growth in a Global Perspective: A PMG Estimation Approach
}

\author{
Abida Hafeez ${ }^{1}$, Karim Bux Shah Syed ${ }^{2}$, Fiza Qureshi ${ }^{2}$ \\ ${ }^{1}$ PhD Scholar, Applied Economic Research Centre (AERC), University of Karachi \\ ${ }^{2}$ Institute of Business Administration, University of Sindh, Jamshoro, Pakistan \\ Correspondence: Syed Karim Bux Shah, Institute of Business Administration, University of Sindh, Jamshoro, \\ Pakistan.
}

Received: February 23, 2019

Accepted: March 8, 2019

Online Published: March 28, 2019

doi:10.5539/ibr.v12n4p163

URL: https://doi.org/10.5539/ibr.v12n4p163

\begin{abstract}
This paper analyses the impact of research and development (R\&D) expenditures on economic growth in a global perspective utilizing the data of 60 developed and developing countries from 1998 to 2015. This study employs the Pooled Mean Group Estimators (PMGE) proposed by Pesaran et al. (1999) to find a heterogeneous trend among different groups of countries. The findings suggest that there exist a significant \& positive relationship amongst $R \& D$ spending and economic growth globally, which appears consistent with economic theory. The study also confirms both long and short run relationship of economic growth and expenditures on R\& D except that the short-run coefficient appears insignificant in the case of developing countries. This study implies that economies with higher R\& D spending tend to have higher economic growth. This study has retentive policy implications for management and policymakers who could make important endeavors at the national level in this regard.
\end{abstract}

Keywords: economic growth, pooled mean group, R \& D expenditures, panel-cointegration

\section{JEL Classification: E23, O32, 047}

\section{Introduction}

Innovation and technological development appear as strong economic indicators that increase both productivity and economic growth simultaneously. It is inevitable to adopt innovation activities along with technological developments to compete worldwide in the era of competition and globalization. R\& D expenditures play a vital role in innovation activities and increase productivity and economic growth. Moreover, investment in R\& D is very important to achieve growth economically in the long-run. (Romer, 1994). Hence, it is necessary to increase $\mathrm{R} \& \mathrm{D}$ expenditures to gain sustainable economic growth and to realize continuous change.

A rise in economic growth is thought to have a trickle-down effect, which, consequently, causes an increase in national wealth and better living standard. Theoretically, the growth rate affects the welfare level of economies. Therefore, it is important to quantify the role of different factors affecting economic growth. Research and development is one of those important factors. Different studies have been conducted to find out the effect of R\& D on GDP growth. These studies vary in their outcomes. Both theoretical and empirical literature shed light on the fact that expenditure on $\mathrm{R} \& \mathrm{D}$ is a crucial factor of sustainable economic growth along with increasing innovation would have a positive impact on productivity. As a result, economies that spend more on R\& D have higher value addition and economic growth.

Theoretically, R\& D activities affect economic growth positively and in a persistent way. Endogenous growth theory provides the basis for developing a growth model by incorporating R\& D activities that rely upon human capital and production of new goods. A model originated in the theoretical background of endogenous growth links expenditures on R\& D and continuous economic growth in the long-run. R\& D expenditures cause technological development and produce new knowledge. As a result, there is an increase in productivity and economic growth.

To achieve high economic growth rate, it is necessary to invest in developing knowledge and technologies. All 
such activities that contribute to achieving high growth rate including new production techniques, efficient use of production methods and introducing novel products are founded on R\& D expenditures. In the era of globalization and competition, spending on technology and innovation activities is inevitable to integrate globally. That's the reason for higher economic growth rate in developed countries where more than 2 percent funds are allocated to R\& D. In Pakistan, allocated funds to R\& D have remained less than $1 \%$ and it was only $0.25 \%$ in 2015 . As a matter of fact, economies that invest more in R\& D development have higher economic growth rate.

The aim of this research study is to investigate the effect of R\& D spending on economic growth in both developed developing countries (in a global perspective) by using data of 60 economies from 1998 to 2015. The hypothesis adopted in the study is to determine the long-run positive and significant relationship of GDP growth and expenditures on R\& D. For the empirical investigation, a novel panel dynamic approach of pooled mean group estimators (PMGE) proposed by Pesaran et al., (1999) has been used. This study also uses panel unit root and panel cointegration tests to find the effect of R\& D outlays on sustainable GDP growth. The research question undertaken in the present study is whether R\& D affects economic growth positively in a large sample of sixty countries. Moreover, this research question has not been investigated incorporating Pakistan previously. The first attempt is being made by taking into account Pakistan in this context. The study combined both developed and developing countries from the European Union, SAARC, ASEAN, and OECD-member countries, Asian and South Asian economies, etc.

The findings support the hypothesis adopted and suggest not only a significant but also a positive relationship between spending on R\&D and GDP growth globally. This outcome is consistent with economic theory. The outcomes of the study also confirm both long and short run relationship of GDP growth and expenditures on R\& D except that the short-run coefficient does not appear significant in case of developing economies. On the whole, the results obtained are in line with theory and empirics. The organization of the study is as follows: Section- 2 contains both empirical and theoretical literature both on R\& D spending and growth. Section-3 presents different data sources and the methodology in detail. The discussion of findings is provided in section-4. The conclusion is offered in section-5.

\subsection{Global R\& D Expenditure Versus Pakistan}

Globally, economies are focusing on competition which is created by technological development and globalization as well. In today's world, R\&D activities are of large grandness to face this competition. It also has a significant effect on an economy's development level which can be measured through the allocation of resources to R\&D expenditures as a percentage (\%) of GDP.

Table 1. Gross Domestic Expenditures on Research \& Development (\% of GDP), 1998-2015

\begin{tabular}{|c|c|c|c|c|c|c|}
\hline Countries & 1998 & 2002 & 2007 & 2011 & 2013 & 2015 \\
\hline Pakistan & 0.109 & 0.220 & 0.633 & 0.329 & 0.293 & 0.246 \\
\hline Turkey & 0.371 & 0.526 & 0.722 & 0.860 & 0.945 & 0.632 \\
\hline China & 0.649 & 1.064 & 1.384 & 1.794 & 2.015 & 2.066 \\
\hline Egypt & 0.199 & 0.194 & 0.255 & 0.532 & 0.678 & 0.723 \\
\hline Mexico & 0.317 & 0.382 & 0.369 & 0.426 & 0.501 & 0.552 \\
\hline India & 0.692 & 0.713 & 0.791 & 0.822 & 0.822 & 0.627 \\
\hline Austria & 1.736 & 2.070 & 2.432 & 2.682 & 2.964 & 3.072 \\
\hline Belgium & 1.824 & 1.891 & 1.844 & 2.155 & 2.430 & 2.457 \\
\hline Denmark & 2.006 & 2.442 & 2.515 & 2.966 & 3.085 & 3.014 \\
\hline Finland & 2.787 & 3.257 & 3.346 & 3.639 & 3.297 & 2.905 \\
\hline France & 2.084 & 2.166 & 2.020 & 2.191 & 2.243 & 2.231 \\
\hline Germany & 2.212 & 2.415 & 2.446 & 2.796 & 2.826 & 2.878 \\
\hline Italy & 1.008 & 1.084 & 1.132 & 1.209 & 1.306 & 1.335 \\
\hline Japan & 2.960 & 3.116 & 3.461 & 3.383 & 3.474 & 3.284 \\
\hline Korea & 2.149 & 2.274 & 3.000 & 3.744 & 4.149 & 4.228 \\
\hline Norway & 1.605 & 1.631 & 1.565 & 1.628 & 1.654 & 1.933 \\
\hline UK & 1.665 & 1.715 & 1.684 & 1.691 & 1.664 & 1.703 \\
\hline USA & 2.497 & 2.550 & 2.627 & 2.763 & 2.725 & 2.794 \\
\hline
\end{tabular}

Source: Eurostat-Database, World Bank

R\&D expenditures both in Pakistan and around the globe indicate variation continuously. During the year of 2007, R\&D spending is the highest i.e. 0.63\% followed by a decline till 2015 instead of a rise in case of Pakistan. However, there is a wide gap between R\&D spending as a share of GDP in Pakistan and developed economies around the world. Most of the developed economies show an increasing trend in their R\& D spending including Italy, Austria, Belgium, Norway, Denmark, Germany, the United Kingdom-(UK), Korea, and the United States of 
America-(USA). Among developing countries, China, Egypt, and Mexico indicate a rising trend in R\&D spending. During 2015, Pakistan has the lowest spending that is $0.25 \%$ among all the countries shown in Table 1 .

\section{The Literature}

This section reviews literature both theoretically and empirically on the relationship of activities related to research and development and economic growth of both developed and developing countries.

\subsection{Theoretical Literature}

Different macroeconomic theories explain the path of economic growth through research and development (R\& D) spending. Therefore, some well-known theories that provide the basis to establish this relationship and highlight its importance over time are as follows:

According to Schumpeter (2003), economic growth is directly affected by innovation activities in a capitalist economy. Romer $(1986,1990)$ explains technological development is a primary source of economic growth and $\mathrm{R} \& \mathrm{D}$ expenditure is an important factor of economic growth. Decreasing return to scale is compensated through investment in human capital which is an outcome of R\&D expenditures. According to Grossman \& Helpman (1991), R\& D spending is crucial to increase in economic growth. Pessoa (2010) argues that different novel ideas, production of new products and the emergence of new markets are the creation of innovation activities related to entrepreneurship.

Globally, different economies are focusing on innovation activities to compete with each other in today's world. Since the 1980s, endogenous growth theory is based on innovation and technology through R\& D sector. R\& D expenditure is considered as a driver of continuous economic growth in the era of globalization and competition. Literature supports R\& D expenditures as an important input to increase economic growth.

A pioneer work by Schumpeter (1970) highlights the importance of innovation which includes new production and sales methods, the emergence of new markets and the manufacturing of new products, etc. Models developed within the scope of R\&D activities are based on different sectors such as product sectors of both finished \& intermediate and research \& development sector which has a substantial role in achieving sustainability in economic growth through innovative ideas of human capital employed.

Initially, two different studies conducted by Romer (1986) and Lucas (1988) provide the basis for the endogenous growth model. According to Romer (1986), technology is very important for economic growth. One aspect of investment is to enhance information technology and knowledge generation which appear as a free input in the production process. As a result, there would be higher return and reduction in costs. Romer's study based on Arrow (1962)' concept i.e. learning-by-doing which, leads to lower costs, quality enhancement and increase in production in an economy as a whole.

Different endogenous growth theories incorporate $R \& D$ expenditure for sustainable economic growth (Romer, 1990; Aghion and Howill, 1992; Grossman and Helpman, 1991). According to Romer (1990), accumulation of knowledge as a result of $\mathrm{R} \& \mathrm{D}$ investments is crucial for the endogenous growth model. It is necessary to increase the number of researchers and R\& $\mathrm{D}$ expenditure to observe long-term economic growth.

Grossman and Helpman $(1984,1990)$ growth models which are based on technological innovation associate economic growth with trade indicators such as foreign trade and openness. Grossman and Helpman (1984) argue that products such as modern industrial and conventional products along with $R \& D$ based on products including technology and knowledge generation. Accordingly, technology enables economies to have a comparative advantage and an increase in growth and global trade. According to Grossman and Helpman (1991), R\&D investments in developing countries can be compensated through technology transfer from developed economies.

Aghion and Howitt (1992) developed a model based on innovation and creative destruction concept of Schumpeter (1970) which explains that innovations play an important role in the overall state of the economy. Rivera-Batiz and Romer (1991) emphasize that government could take appropriate policy measures to promote R\&D activities. These activities foster economic growth. In this regard, the Government needs to support both institutions and activities related to research and development (R\&D) through sound regulation.

Various theories during this decade highlight the importance of investment in R\&D. Planned economic behavior and human capital affect long-term economic growth (Verbic et al., 2011). Investment in both R\& D along with human capital is a primary determinant to increase efficiency. Investments in R\& D through different channels like capital accumulation, human resource development, and innovation affect economic growth (Bor et al., 2012). 
Evenson (1997) categorizes growth literature. Firstly, the post-Keynesian model which emphasized saving and investment to increase economic growth. Secondly, Neo-Classical growth models emphasize on external technical progress to encourage economic growth. Thirdly, the economic growth model emphasized R\& D and human capital to determine long-run economic growth.

R\& D generates profitability and also has spillover effects in the form of knowledge and information, etc. Kim (2011) links R\& D to productivity. Spillover effects of R\& D are known as knowledge transmission which leads towards innovation.

Theoretical literature is also foregrounded the fundamental role of $\mathrm{R} \& \mathrm{D}$ in growth at aggregate and disaggregate levels. Innovation and R\& D activities are drivers of growth in different sectors such as industrial and service (Gerybadze, 2010). R\& D plays a central role in the efficiency and economic growth (Samimi and Alerasoul, 2009). R\& $D$ is the fundamental determinant of long-term efficiency and consumer wealth (Jones and William, 2000). Peng (2010) regards R\& D as a key factor for future growth. Bilbao and Rogriguez (2004) argue that investment in R\& D is a key determinant of innovation, economic growth and to secure technological potential.

\subsection{Empirical Literature}

International spillover effects of $\mathrm{R} \& \mathrm{D}$ on different factors such as total factor productivity, output, organizational differences, small-medium size enterprises are found by different researchers (Nadiri and Kim, 1996; Coe et al., 2008; Nunes et al., 2012). Funke and Niebuhr (2000) find regional spillover effects on economic growth which are considered significant for near-by regions geographically.

Various panel studies have been conducted to find out the effects of spending in R\& D on economic growth in economically well-developed economies such as OECD-member countries. Freire-Serein (1999), Altıntaş and Mercan (2015) and Bassanini ve Scarpetta (2001) found not only a positive but also significant association between investment in R\& D and growth in twenty-one OECD economies. A similar relationship is also found by Sylwester (2001) for G7 countries, Özer ve Çiftçi (2008) for all OECD countries and Saraç (2009) for ten OECD countries during 1983-2004. Falk (2007) detects a long-term significance and positive effects of R\& D activities on income for the period of 1970-2004. Zachariadis (2004) analyses the manufacturing industrial data from 1971 to 1995 . The findings indicate that output and efficiency are positively affected by R\& D activities. Gülmez and Yardımcıoğlu (2012) find a strong long-term relationship between economic growth rates and stock of R\& D after analyzing both macroeconomic variables in OECD-member economies from 1990 to 2010.

Ulku (2004) finds out that a significant impact of R\& D on innovation activities is found in twenty OECD economies and a positive relationship is also found between GDP per capita and innovation in a total sample of thirty countries. Another panel study conducted by Yanyun and Mingqian (2004) depicts that there exists an ascertaining relationship amongst $\mathrm{R} \& \mathrm{D}$ expenditures and growth for Korea, Japan, China and eight ASEAN economies for 1994-2003. Cluster analysis is conducted by Şimşek ve Behdioğlu (2006) between Turkey and OECD economies to examine the important association relationship between both growth and R\& D from 1999 to 2002. The finding indicates that R\& D indicators of Turkey lag behind OECD countries. However, investment in R\& D appeared to be a fundamental determinant of productivity in different panel studies (Lichtenberger, 1993; Park, 1995; Coe et al., 1995 and Guellec and van Pottelsberghe, 2004).

Genç and Atasoy (2010) find a unilateral causal relation between R\&D spending and growth from 1997 to 2008 through causality method. Similar results are found by Yaylalı, Akan and Işı (2010) in the case of Turkey for the period of 1990-2009. Sadraoui et al. (2014) also used causality method to find the relationship between economic growth and R\& D collaboration employing data on thirty-two developed and industrialized countries over the period of 1970-2012. The results depict a strong causal relation of growth and R\&D. Another study using causality approach by Altın and Kaya (2009) ascertains a long-term causality running from R\&D spending to economic growth in the case of Turkey for 1990-2005. Güloğlu and Tekin (2012) found bidirectional causalities between growth \& technological innovation and R\&D \& for 13 OECD countries during 1991-2007. Bozkurt (2015) finds out a unidirectional causality from growth to GDP in Turkey during 1998-2013. GDP growth is increased by 0.26 percent as a result of $1 \%$ rise in R\& D as a share of GDP.

Empirical studies also highlight the association between R\& D and growth rate at individual country level instead of considering different economies at the group level. Horowitz (1967) analyses consistency between R\& $\mathrm{D}$ activities and regional growth rates in different states of the United States of America over the period of 1920-1964. He finds satisfactory results. Kim (2009) investigates the relationship of R\& D activities and growth through Cobb-Douglas production function for the period of 1976-2009 in case of Korea. The results quantify the contribution of R\&D expenditures by about 35 percent in economic growth. Peng (2010) finds a strong association of growth and outlays on $\mathrm{R} \& \mathrm{D}$ for China. 
Various empirical studies have been conducted by different researchers to confirm the association between investments in R\& D and GDP growth in different countries in the long-run employing different type of models. These studies confirm not only a positive but also a significant relationship in the long-run (Korkmaz, 2010; Taban and Şengür, 2013; Goel et al., 2008; Horvath, 2011 and Segerstrom, 2000).

Gumus and Celikay (2015) analyzed R\& D activities' contribution to the GDP growth, comparing developing and developed economies. They found: "R\&D expenditure has a positive and significant effect on economic growth for all countries in the long run, excluding developing countries where the effect is weak in the short run but strong in the long run."

\section{Data and Methodology}

The annual data on both variables including R\&D expenditures and GDP at current US\$ is retrieved from different sources such as World Development Indicators of World Bank (WDI-2017), the Statistical Office of the European Union (Eurostat-2017), UNESCO-2017 and different reports of Asian Development Bank (ADB) and OECD from 1998-2015. A total of sixty economies are included in the global sample1, of which thirty-six are developed countries and twenty-four are developing countries.

\subsection{The Panel Unit Root Tests}

In this study, a pooled mean group estimators (PMGE) approach is used to determine the relation of R\& D expenditures to GDP growth both in short and long-run. However, it is required to conduct stability analysis of different variables through appropriate unit root tests of Breitung (2000) along with Maddala and Wu (1999) for balanced panel data where the numbers of cross-section units $(\mathrm{N})$ are greater than time-series units $(\mathrm{T})$. Maddala and $\mathrm{Wu}(1999)$ test is based on Fisher-ADF and Fisher-PP tests to test the assumption of different autocorrelation among the panel units; Breitung (2000) examines the assumption of common autocorrelation in the panel units.

\subsection{The Econometric Model}

In this research paper, the canonical hypothesis that is founded on the endogenous growth model is tested through the following functional relationship:

$$
\Delta Y=f(\Delta X, \text { OtherFactors })
$$

Where ' $\mathrm{Y}$ ' represents the Gross Domestic Product (GDP growth) and ' $\mathrm{X}$ ' indicates R\& D expenditures. The econometric model takes the following form under the hypothesis that "there exists a long-term positive and significant relationship between R\&D expenditures and economic growth". The basic model for panel data is as follows:

$$
Y_{i t}=\alpha_{\mathrm{o}}+\beta_{\mathrm{O}} X_{i t}+\mu_{i t}
$$

Where, $\mathrm{i}=1, \ldots ., \mathrm{N}$ and $\mathrm{t}=1, \ldots, \mathrm{T} ; \mathrm{N}$ represents the number of economies included in the sample and $\mathrm{T}$ is time period taken in this panel analysis.
i: $1, \ldots \ldots, 60$ (Global Sample)
t: $1, \ldots \ldots \ldots . . ., 18(1998-2015)$
i: $1, \ldots \ldots, 36$ (Developed Countries)
t: $1, \ldots \ldots \ldots . . ., 18(1998-2015)$
i: $1, \ldots \ldots, 24$ (Developing Countries)
t: $1, \ldots \ldots \ldots \ldots, 18(1998-2015)$

\subsection{Panel-Cointegration Test: Pedroni Test}

After the panel unit root analysis, this paper applies panel-cointegration methodology proposed by Pedroni (1999) to examine whether panel units are heterogeneous or not. To test the heterogeneity among panel units is quite realistic rather than assuming that vectors are identical. Pedroni test takes the following form to estimate the long

\footnotetext{
${ }^{1}$ The global sample is tested for causality and finds unidirectional-causality from $\mathrm{X}$ ( $\mathrm{R} \& \mathrm{D}$ ) to $\mathrm{Y}$ (Economic Growth) where F-Stat. is $5.74 \quad(\mathrm{P}=0.003)$. Statistics for $\mathrm{Y}(\mathrm{Mean}=2.48$ \& St. Dev. $=5.83)$ and for $\mathrm{X}$ (Mean $=1.81 \&$ St. Dev. $=1.01)$. The global sample includes following countries: Austria, Canada, Hong Kong, Czech Republic, France, Cyprus, Germany, Spain, Belgium, Italy, Portugal, Ireland, Japan, Latvia, Estonia, UK, Norway, Croatia, Poland, Russian, USA, Trinidad \& Tobago, Netherlands, Singapore, Kuwait, Slovak Republic, Denmark, Iceland, Slovenia, Finland, Sweden, Israel, Korea, Lithuania, Greece, Uruguay, Argentina, Bulgaria, China, Azerbaijan, Colombia, Belarus, Cuba, Serbia, Egypt, Armenia, Hungary, Kazakhstan, Panama, Mexico, Romania, Thailand, Tunisia, Ukraine, Kyrgyz Republic, Madagascar, Costa Rica, Turkey, India, and Pakistan
} 
run relationship:

$$
\begin{gathered}
\ln \left(Y_{i t}\right)=\alpha_{i}+v_{i} t+\beta_{1 i} \ln \left(X_{i t}\right)+\varepsilon_{i t} \\
\hat{\varepsilon}_{i t}=\hat{\rho}_{i} \hat{\varepsilon}_{i t-1}+\hat{\mu}_{i t}
\end{gathered}
$$

Equation (3) indicates the estimated residuals. Pedroni classified seven statistics in two categories namely "Within Dimension" and "Between Dimension". The former category consists of four-panel statistics and later one includes three-group statistics under the null hypothesis (H0) of 'non-cointegration'.

\subsection{Estimation of Panel-Cointegration: Pooled Mean Group Estimator (PMGE)}

The panel cointegration models are used to predict the long-run relationship between macroeconomic variables based on economic theory. These models are helpful in estimating the regression coefficients and examining theoretical restrictions. There are different panel cointegration methods that are efficient asymptotically. Two types of econometric models are used to analyze panel data frequently. Firstly, the MGE (Mean Group Estimators) of Pesaran and Smith (1995) is appropriate for heterogeneity in both short-term and long term. Its efficiency is subject to a large sample (Pirotte, 1999). Secondly, methods include fixed or random effects and GMM allow equality across panel units.

However, the PMGE (Pooled Mean Group Estimators) is somewhere in the middle of both above-mentioned methods. The pooled mean group estimator (PMGE) suggested by Pesaran et al., (1999) takes into account heterogeneity in panel units only in short run, assuming that these units are homogenous instead of heterogeneous in the long-term. That's the reason; the PMGE is preferred to other panel cointegration tests. In contrast to fully modified (FM) and the dynamic ordinary least squares (DOLS) methodology, the PMGE shows the speed of adjustment of short-term dynamics towards long-term. The null hypothesis (H0) of the PMG estimator is that 'long run coefficient is homogenous' would be examined through the Hausman test. The PMGE would proceed as follows:

$$
\ln \left(Y_{i t}\right)=\alpha_{0}+\beta_{0} \ln \left(X_{i t}\right)+\mu_{i t}
$$

The lag length criteria of AIC (Akaike Information Criterion) and SIC (Schwarz information Criterion) have been used to select a maximum lag length for $\operatorname{In}(\mathrm{Y})$ and $\operatorname{In}(\mathrm{X})$ i.e. one lag. It is assumed that both $\mathrm{In}(\mathrm{Y})$ and In (X) are of integrated of order one i.e. I (1) and residuals are of I (0). So the pooled mean group estimators/ ARDL $(1,1)$ model of Pesaran et al. (1999) takes the following form:

$$
\ln \left(Y_{i t}\right)=\eta_{i}+\omega_{i} \ln \left(Y_{i, t-1}\right)+v_{0 i} \ln \left(X_{i t}\right)+v_{1 i} \ln \left(X_{i, t-1}\right)+\varepsilon_{i t}
$$

To find the long run adjustment speed, error correction model (ECM) would be as follows:

$$
\Delta \ln \left(Y_{i t}\right)=\phi_{i}\left(\ln Y_{i, t-1}-\hat{\tau}_{0 i}-\hat{\tau}_{1 i} \ln \left(X_{i, t-1}\right)+v_{1 i} \ln X_{i t}+\varepsilon_{i t}\right.
$$

Where,

$$
\phi_{i}=-\left(1-\omega_{i}\right), \hat{\tau}_{0 i}=\frac{\eta_{i}}{\left(1-\omega_{i}\right)}, \hat{\tau}_{1 i}=\frac{\nu_{0 i}+v_{1 i}}{\left(1-\omega_{i}\right)}
$$

\section{The Empirical Results}

\subsection{The Results of the Panel Unit Root Tests}

Table 2 demonstrates the results of stability analysis for panel datasets including Maddala and Wu (1999) along with Breitung (2000). The results highlight that both variables appear non-stationary in level and the null hypothesis (H0) of panel unit root tests cannot be rejected for all the samples undertaken. However, all datasets including global sample and both developed $\&$ developing countries indicate that both variables are stationary in first differences at $1 \%$ and $5 \%$ level of significance. Therefore, these findings lead to apply panel cointegration 
test proposed by Pedroni (1999) to confirm the relationship between variables (research \& development and GDP growth) undertaken in the long-run.

Table 2. Panel Unit Root- Results

\begin{tabular}{|c|c|c|c|c|c|c|c|}
\hline & \multicolumn{4}{|c|}{ Maddala and Wu (1999) } & \multirow{2}{*}{\multicolumn{2}{|c|}{ Breitung (2000) }} & \multirow{3}{*}{ Decision about $H_{0}$} \\
\hline & \multicolumn{2}{|c|}{ Fisher-ADF } & \multicolumn{2}{|c|}{ Fisher-PP } & & & \\
\hline & Stat. & Prob. & Stat. & Prob. & Stat. & Prob. & \\
\hline \multicolumn{8}{|c|}{ Global Sample } \\
\hline$Y_{i t}$ & 0.505 & 0.693 & 3.494 & 0.999 & 3.245 & 0.999 & Accept \\
\hline$\Delta Y_{i t}$ & $-5.845^{*}$ & 0.000 & $-8.713 *$ & 0.000 & $-1.797 * *$ & 0.036 & $\underline{\text { Reject }}$ \\
\hline$X_{i t}$ & 0.912 & 0.819 & 2.484 & 0.993 & 2.829 & 0.997 & Accept \\
\hline$\Delta X_{i t}$ & $-13.80 *$ & 0.000 & $-15.74 *$ & 0.000 & $-6.031 *$ & 0.000 & Reject \\
\hline \multicolumn{8}{|c|}{ Developed Countries } \\
\hline$Y_{i t}$ & 1.095 & 0.863 & 1.215 & 0.888 & -0.095 & 0.462 & Accept \\
\hline$\Delta Y_{i t}$ & $-3.387^{*}$ & 0.000 & $-5.741 *$ & 0.000 & $-2.255 * *$ & 0.012 & $\underline{\text { Reject }}$ \\
\hline$X_{i t}$ & 0.102 & 0.540 & 2.337 & 0.990 & 1.830 & 0.966 & Accept \\
\hline$\Delta X_{i t}$ & $-9.670 *$ & 0.000 & $-10.60 *$ & 0.000 & $-4.424 *$ & 0.000 & Reject \\
\hline \multicolumn{8}{|c|}{ Developing Countries } \\
\hline$Y_{i t}$ & 2.896 & 0.998 & 3.778 & 0.999 & -1.420 & 0.078 & Accept \\
\hline$\Delta Y_{i t}$ & $-1.779 * *$ & 0.038 & $-4.460 *$ & 0.000 & $-3.761 *$ & 0.000 & Reject \\
\hline$X_{i t}$ & 2.708 & 0.996 & 1.723 & 0.957 & 2.100 & 0.982 & $\overline{\text { Accept }}$ \\
\hline$\Delta X_{i t}$ & $-10.79 *$ & 0.000 & $-16.32 *$ & 0.000 & $-4.102 *$ & 0.000 & Reject \\
\hline
\end{tabular}

Notes. Rejection of $\mathrm{H}_{0}=$ non-stationary at $1 \%$ level of significance is indicated by $(*)$, or $5 \%$ by (**).

\subsection{The Results of Pedroni Panel-Cointegration Test}

Table 3 shows the findings of panel cointegration test of Pedroni (1999), which consists of seven-type of statistics under the two categories of Within-Dimension (Panel) consisting of four statistic out of seven and Between-Dimension (Group) has three statistics to test that whether R\& D activities and GDP growth are co-integrated in the long-run or not under the null hypothesis of 'non- cointegration'.

Table 3. Pedroni Panel Cointegration Test- Results

\begin{tabular}{|c|c|c|c|c|c|c|}
\hline \multicolumn{7}{|c|}{ Within-Dimension (Panel) } \\
\hline & \multicolumn{2}{|c|}{$\begin{array}{l}\text { Global } \\
\text { Sample }\end{array}$} & \multicolumn{2}{|c|}{$\begin{array}{c}\text { Developed } \\
\text { Countries }\end{array}$} & \multicolumn{2}{|c|}{$\begin{array}{l}\text { Developing } \\
\text { Countries }\end{array}$} \\
\hline Panel & Stat. & Prob. & Stat. & Prob. & Stat. & Prob. \\
\hline$v_{-}$Statistics & $1.947 * *$ & 0.025 & $2.982 *$ & 0.001 & 0.223 & 0.412 \\
\hline rho_Statistics & $-10.96 *$ & 0.000 & $-7.306^{*}$ & 0.000 & $-7.745^{*}$ & 0.000 \\
\hline PP_Statistics & $-14.53 *$ & 0.000 & $-9.807 *$ & 0.000 & $-10.16^{*}$ & 0.000 \\
\hline ADF_Statistics & $-10.66^{*}$ & 0.000 & $-9.352 *$ & 0.000 & $-5.948 *$ & 0.000 \\
\hline \multicolumn{7}{|c|}{ Between-Dimension(Group) } \\
\hline & \multicolumn{2}{|c|}{$\begin{array}{l}\text { Global } \\
\text { Sample }\end{array}$} & \multicolumn{2}{|c|}{$\begin{array}{c}\text { Developed } \\
\text { Countries }\end{array}$} & \multicolumn{2}{|c|}{$\begin{array}{c}\text { Developing } \\
\text { Countries }\end{array}$} \\
\hline Group & Stat. & Prob. & Stat. & Prob. & Stat. & Prob. \\
\hline rho_Statistics & $-4.504 *$ & 0.000 & $-2.932 *$ & 0.002 & $-3.531 *$ & 0.000 \\
\hline PP_Statistics & $-13.17 *$ & 0.000 & $-9.427 *$ & 0.000 & $-9.274^{*}$ & 0.000 \\
\hline ADF_ Statistics & $-11.08 *$ & 0.000 & $-9.88 *$ & 0.000 & $-5.425^{*}$ & 0.000 \\
\hline
\end{tabular}

Notes. Rejection of $\mathrm{H}_{0}=$ non-cointegration at $1 \%$ level of significance is indicated by $(*)$, or $5 \%$ by (**).

The former category has four-type of statistics polling autoregressive coefficients across all cross-section units of the panel and later one has three-type of statistics that averages out autoregressive coefficients of each cross-sectional unit of the panel. All types of statistics indicate that the null hypothesis (H0) can be rejected at $1 \%$ and $5 \%$ level of significance except that the null hypothesis of v-Statistics cannot be rejected in the case of developing countries. Therefore, economic growth and R\&D spending are cointegrated in the long run for all panel datasets. The appearance of a long-term association between the variables verifies the endogenous growth model. Having found that two-variables are cointegrated in long-run, it paves the way to estimate the coefficient of adjustment using a panel-cointegration estimator. For this purpose, this research paper employs the Pooled Mean Group Estimators (PMGE).

\subsection{The Results of the Pooled Mean Group Estimators (PMGE)}

Table 4 reports the findings of PMG estimators of both short and long run coefficients along with the coefficient of adjustment (convergence parameter). A study conducted by Pesaran et al., (1999) is followed for the estimation of cointegration equations for the global sample and in case of both developed and developing countries. The speed of adjustment from short-term to long term is shown by convergence parameter that 
highlights the homogenous trend in coefficients of research and development (R\& D) spending and GDP growth across the cross-sectional units of the panel. The coefficient of adjustment $(-0.71)$ is significant at $1 \%$ level of significance and has expected sign. The findings reveal the adjustment dynamic in ${ }_{2} \mathrm{R} \& \mathrm{D}$ expenditures from short to long-run equilibrium across countries in the global sample. The chi-square $\left(\chi^{2}\right)$ values of the Hausman test show that the null hypothesis, 'the long-run coefficient is homogenous', can not be rejected at levels of $1 \%$ or $5 \%$ in all cases. Therefore, the PMGE is appropriate to enquire the relationship of R\& D spending and economic growth globally. These results are also supported by Bangake and Eggoh (2012) where the PMGE is considered appropriate to capture homogeneity.

Table 4. Pooled Mean Group Estimators (PMGE)-Results

\begin{tabular}{|c|c|c|c|c|c|c|}
\hline & \multicolumn{2}{|c|}{$\begin{array}{l}\text { Global } \\
\text { Sample }\end{array}$} & \multicolumn{2}{|c|}{$\begin{array}{l}\text { Developed } \\
\text { Countries }\end{array}$} & \multicolumn{2}{|c|}{$\begin{array}{c}\text { Developing } \\
\text { Countries }\end{array}$} \\
\hline & Stat. & Prob. & Stat. & Prob. & Stat. & Prob. \\
\hline LR Coefficient & $0.969 *$ & 0.000 & $0.975^{*}$ & 0.002 & $0.938 * *$ & 0.013 \\
\hline SR Coefficient & $0.266^{* *}$ & 0.029 & $0.194 * *$ & 0.033 & 0.467 & 0.448 \\
\hline Constant & $0.045^{*}$ & 0.000 & $0.043^{*}$ & 0.000 & $-0.047 *$ & 0.000 \\
\hline Adjustment Coeffiçient & $-0.713^{*}$ & 0.000 & $-0.699 *$ & 0.000 & $-0.730^{*}$ & 0.000 \\
\hline Hausman Test $\left(\chi^{2}\right)$ & 1.013 & 0.314 & 1.528 & 0.216 & 0.872 & 0.350 \\
\hline No. of Observations & \multicolumn{2}{|c|}{1080} & \multicolumn{2}{|c|}{648} & \multicolumn{2}{|c|}{432} \\
\hline No. of Countries & \multicolumn{2}{|c|}{60} & \multicolumn{2}{|c|}{36} & \multicolumn{2}{|c|}{24} \\
\hline
\end{tabular}

ARDL $(1,1)$

For the global sample, the coefficient of adjustment is both significant and negative at the level of $1 \%$. This finding demonstrates that there exists a long-term association of R\& D expenditure and GDP growth globally. This finding is similar as reported by Gumus and Celikay (2015). These findings reveal that an increment of $1 \%$ in $\mathrm{R} \& \mathrm{D}$ spending leads to raising economic growth by $0.27 \%$ in the short-run (SR) and $0.97 \%$ in the long run (LR). In the context of developed and developing countries, the convergence parameter also appears negative and significant confirming the long-term relationship of economic growth and $\mathrm{R} \& \mathrm{D}$ expenditure. According to results for developed economies, if there is $1 \%$ rise in R\&D spending, economic growth would be raised by about $1 \%$ (i.e. $0.98 \%$ ) in the long run (LR) and less than half of $1 \%$ increase in growth $(0.19 \%)$ in the short-run (SR). This outcome is also supported by Bozkurt (2015) in terms of significance and positivity of both macroeconomic indicators. However, developing countries' results are insignificant but positive for the short run. This difference in results can be ascribed to the differences in capital stock and productivity which play a substantial role in economic growth and activities based on R\&D.

The PMGE provides the results that short-term coefficients are significant for the developed countries and global sample. However, the short-term coefficient is insignificant in the case of developing economies reflecting that there is a lack of short-term relation between R\& D spending and economic growth. Moreover, short run (SR) coefficient indicates that how the economy is adjusted to shocks, in case of developing countries, the contemporaneous co-movements of both variables (R\&D and economic growth) do not respond to past shocks. This outcome is in line with that of Inekwe (2014). On the other hand, the long run (LR) coefficient appears significant at $1 \%$ and $5 \%$ levels of significance for all specifications of sample undertaken in this study. However, long term effects are dominated than those of short-term effects of R\& D outlays on growth for the global sample and developed economies along with developing ones.

On the whole, the outcomes confirm the hypothesis undertaken in this study. There exists one-to-one relationship in the long run in macroeconomic series undertaken for analysis but this outcome differs with respect to significance and magnitude only in the context of developing economies in the short run. However, all the specifications of sample depict that endogenous growth model is valid for all economies in the long-run.

\section{Concluding Remarks}

This paper tries to investigate the impact of spending in research and development (R\& D) on economic growth in a global perspective including both developed and developing countries from 1998-2015. This study applies the Pooled Mean Group Estimators (PMGE) suggested by Pesaran et al., (1999) to find a heterogeneous trend among a different group of countries. According to economic theory, a rise in R\&D spending affects economic growth positively and significantly. It implies that changes in R\&D based activities would impact economic growth, employment level, productivity, innovation and trade activities, and technological developments. The findings of this study defend the economic theory. 
The findings suggest that there exist a significant \& positive association of R\& D spending and GDP growth globally. This finding is similar to that of Gumus and Celikay (2015). The study also confirms both long and short run relationship of R\& D and economic growth except that short-run coefficient appears insignificant in the case of developing countries. This study implies that economies with higher R\& D spending tend to have higher economic growth. Concerning the developing countries versus developed countries, the economic growth is lower in the former, implies that there is dire need to increase R\& D expenditures to raise the economic growth both in long and short-run. The findings of this study are of main concern for management and policymakers who could make important endeavors at the national level in this regard.

\section{References}

Aghion, P., \& Howitt, P. (1992). A model of growth through creative destruction. Econometrica, 60(2), 323-351. https://doi.org/10.3386/w3223

Altin, O., \& Kaya, A. A. (2009). Türkiye'de Ar-Ge Harcamalari Ve Ekonomik Büyüme Arasindaki Nedensel İlişkinin Analizi. [Analysis of the casual relationship between R\&D expenditures and economic growth for Turkey]. Ege Akademik Bakuş Dergisi, 9(1), 251-259.

Altıntaş, H., \& Mercan, M. (2015). AR-GE Harcamaları ve Ekonomik Büyüme İlişkisi: OECD Ülkeleri Üzerine Yatay Kesit Bağımlılığı Altında Panel Eşbütünleşme Analizi. [The relationship between research and development (R\&D) expenditures: Panel cointegration analysis under cross sectional dependency on OECD countries]. Ankara Üniversitesi SBF Dergisi, 70(2), 345-376. https://doi.org/10.1501/SBFder_0000002355

Arrow, J. K. (1962). The economic implications of learning by doing. The Review of Economic Studies, 29(3), 155-173. https://doi.org/10.2307/2295952

Baltagi, B. H. (2005). Econometric analysis of panel data (3rd ed.). West Sussex: John Wiley Sons.

Bangake, C., \& Eggoh, J. C. (2012). Pooled mean group estimation on international capital mobility in African countries. Research in Economics, 66(1), 7-17. https://doi.org/10.1016/j.rie.2011.06.001

Bassanini, A., \& Scarpetta, S. (2002). The driving forces of economic growth. OECD Economic studies, 2001(2), 9-56. https://doi.org/10.1787/eco_studies-v2001-art10-en

Bilbao-Osorio, B., \& Rodríguez-Pose, A. (2004). From R\&D to innovation and economic growth in the EU. Growth and Change, 35(4), 434-455. https://doi.org/10.1111/j.1468-2257.2004.00256.x

Bor, Y. J., Chuang, Y. C., Lai, W. W., \& Yang, C. M. (2010). A dynamic general equilibrium model for public R\&D investment in Taiwan. Economic Modelling, 27(1), 171-183. https://doi.org/10.1016/j.econmod.2009.08.007

Bozkurt, C. (2014). R\&D expenditures and economic growth relationship in Turkey. International Journal of Economics and Financial Issues, 5(1), 188-198.

Breitung, J. (2000). The Local Power of Some Unit Root Tests for Panel Data. In B. Baltagi (Ed.), Non-stationary Panels, Panel Cointegration and Dynamic Panels. Advances in Econometrics, 15, 161-178. Amsterdam: Jai Press. https://doi.org/10.1016/S0731-9053(00)15006-6

Coe, D. T., Helpman, E., \& Hoffmaister, A. W. (1997). North-south R \& D spillovers. The Economic Journal, 107(440), 134-149. https://doi.org/10.1111/1468-0297.00146

Coe, D. T., Helpman, E., \& Hoffmaister, A. W. (2009). International R\&D spillovers and institutions. European Economic Review, 53(7), 723-741. https://doi.org/10.1016/j.euroecorev.2009.02.005

Evenson, R. E. (1997). Economic growth, international technological spillovers and public policy: Theory and empirical evidence from Asia. Yale University, Economic Growth Center, Discussion Paper No. 777.

Falk, M. (2007). R\&D spending in the high-tech sector and economic growth. Research in economics, 61(3), 140-147. https://doi.org/10.1016/j.rie.2007.05.002

Freire-Ser, M. J. (1999). Aggregate R\&D expenditure and endogenous economic growth. UFAE and IAE Working Papers 436.

Funke, M. N., \& Annekatrin. (2000). Spatial R\&D spillovers and economic growth: evidence from West Germany, No 98, HWWA Discussion Papers, Hamburg Institute of International Economics (HWWA).

Genç, M. C., Atasoy, Y. (2010). Ar-Ge Harcamaları ve Ekonomik Büyüme İlişkisi: Panel Veri Analizi. The Journal of Knowledge Economy \& Knowledge Management, 9, 27-34.

Gerybadze, A. (2010). R\&D, innovation and growth: Performance of the world's leading technology 
corporations. In Innovation and International Corporate Growth. 11-30. Springer, Berlin, Heidelberg. https://doi.org/10.1007/978-3-642-10823-5_2

Goel, R. K., Payne J. E., \& Ram. (2008). R\&D expenditures and U.S. economic growth: A disaggregated approach. Journal of Policy Modeling, 30, 237-250. https://doi.org/10.1016/j.jpolmod.2007.04.008

Grossman, G. M., \& Helpman, E. (1990). Comparative advantage and long-run growth. The American Economic Review, 80(4), 796-815.

Grossman, G. M., \& Helpman, E. (1991). Innovation and growth in the global economy. Cambridge, The MIT Press.

Guellec, D., \& Van Pottelsberghe de la Potterie, B. (2004). From R\&D to productivity growth: Do the institutional settings and the source of funds of R\&D matter? Oxford Bulletin Of Economics And Statistics, 66(3), 353-378. https://doi.org/10.1111/j.1468-0084.2004.00083.x

Gülmez, A., \& Yardımcığlu, F. (2012). OECD Ülkelerinde Ar-Ge Harcamaları ve Ekonomik Büyüme İlişkisi: Panel Eşbütünleşme ve Panel Nedensellik Analizi (1990-2010). [The relationship between R\&D expenditures and economic growth in OECD countries: Panel cointegration and panel causality analyses (1990-2010). Maliye Dergisi, 163(1), 335-353.

Güloğlu, B., \& Tekin, R. B. (2012). A panel causality analysis of the relationship among research and development, innovation, and economic growth in high-income OECD countries. Eurasian Economic Review, 2(1), 32-47.

Gumus, E., \& Celikay, F. (2015). R\&D expenditure and economic growth: New empirical evidence. The Journal of Applied Economic Research, 9(3), 205-217. https://doi.org/10.1177/0973801015579753

Horowitz, I. (1967). The relationship between interstate variations in the growth of R\&D and economic activity. IEEE Transactions on Engineering Management, 3, 135-141. https://doi.org/10.1109/TEM.1967.6448339

Horvath, R. (2011). Research and development and gowth: A Bayesian model averaging analysis. Economic Modelling, 28, 2669-2673. https://doi.org/10.1016/j.econmod.2011.08.007

Inekwe, J. N. (2015). The contribution of R\&D expenditure to economic growth in developing economies. Social Indicators Research, 124(3), 727-745. https://doi.org/10.1007/s11205-014-0807-3

Jones, C. I., \& Williams, J. C. (2000). Too much of a good thing? The economics of investment in R\&D. Journal of Economic Growth, 5(1), 65-85. https://doi.org/10.1023/A:1009826304308

Kim, L. W. (2011). The Economic growth effect of R\&D activity in Korea. Korea and the World Economy, 12(1), $25-44$.

Korkmaz, S. (2010). Türkiye'de ar-ge yatirimlari ve ekonomik büyüme arasindaki ilişkinin var modeli ile analizi. [Research and Development Investments in Turkey and The Relationship Examined Between Economic Development with VAR Model ] Journal of Yaşar University, 5(20), 3320-3330.

Lichtenberg, F. R. (1992). R\&D investment and international productivity differences (No. w4161). National Bureau of Economic Research. https://doi.org/10.3386/w4161

Lucas, J. R. E. (1988). On the mechanics of economic development. Journal of monetary economics, 22(1), 3-42. https://doi.org/10.1016/0304-3932(88)90168-7

Maddala, G. S., \& Wu, S. (1999). A Comparative Study of Unit Root Tests with Panel Data and a New Simple Test, Oxford Bulletin of Economics and Statistics 61, 631-652. https://doi.org/10.1111/1468-0084.0610s1631

Nadiri, M. I., \& Kim, S. (1996). International $R \& D$ spillovers, trade and productivity in major OECD countries (No. w5801). National Bureau of Economic Research. https://doi.org/10.3386/w5801

Nunes, P. M., Serrasqueiro, Z., \& Leitão, J. (2012). Is there a linear relationship between R\&D intensity and growth? Empirical evidence of non-high-tech vs. high-tech SMEs. Research Policy, 41(1), 36-53. https://doi.org/10.1016/j.respol.2011.08.011

Özer, M., \& Çiftçi, N. (2008). Ar-Ge Tabanlı İçsel Büyüme Modelleri ve Ar-Ge Harcamalarının Ekonomik Büyüme Üzerine Etkisi: OECD Ülkeleri Panel Veri Analizi. [R\&D Based Endogenous Growth Models and Impact of R\&D Expenditures on Economic Growth: OECD Countries Panel Data Analysis]. SÜ Sosyal ve Ekonomik Araştırmalar Dergisi, 10(16), 219-239.

Park, W. G. (1995). International R\&D spillovers and OECD economic growth. Economic Inquiry, 33(4), 
571-591. https://doi.org/10.1111/j.1465-7295.1995.tb01882.x

Pedroni, P. (1999). Critical values for cointegration tests in heterogeneous panels with multiple regressors, Oxford Bulletin of Economics and Statistics, 61, 653-678. https://doi.org/10.1111/1468-0084.0610s1653

Peng, L. (2010). Study on relationship between R\&D expenditure and economic growth of China. Proceedings of the 7th International Conference on Innovation \& Management, 1725-1728.

Pesaran, M. H., \& Smith, R. (1995). Estimating long-run relationships from dynamic heterogeneous panels, Journal of Econometrics, 68(1), 79-113. https://doi.org/10.1016/0304-4076(94)01644-F

Pesaran, M. H., Shin, Y., \& Smith, R. P. (1999). Pooled mean group estimation of dynamic heterogeneous panels. Journal of the American Statistical Association, 94(446), 621-634. https://doi.org/10.1080/01621459.1999.10474156

Pessoa, A. (2010). R\&D and economic growth: How strong is the link? Economics Letters, 107(2), 152-154. https://doi.org/10.1016/j.econlet.2010.01.010

Pirotte, A. (1999). Convergence of the static estimation toward long run Effects of dynamic panel data models, Economics Letters, 53, 151-158. https://doi.org/10.1016/S0165-1765(99)00023-3

Rivera-Batiz, L. A., \& Romer, P. M. (1991). International trade with endogenous technological change. European Economic Review, 35(4), 971-1001. https://doi.org/10.1016/0014-2921(91)90048-N

Romer, M. P. (1986). Increasing returns and long run growth. The Journal of Political Economy, 94(5), 1002-1037. https://doi.org/10.1086/261420

Romer, M. P. (1990). Endogenous technological change. The Journal of Political Economy, 98(5), 71-102. https://doi.org/10.1086/261725

Romer, P. (1994). The origins of endogenous growth. Journal of Economic Perspectives, 1, 3-22. https://doi.org/10.1257/jep.8.1.3

Sadraoui, T., Ali, T. B., Deguachi, B. (2014). Economic growth and international R\&D cooperation: A panel Granger causality analysis. International Journal of Econometrics and Financial Management, 2(1). 7-21.

Samimi, A. J., Alerasoul, S. M. (2009). R\&D and economic growth: New evidence from some developing countries. Australian Journal of Basic and Applied Sciences, 3(4), 3464-3469.

Sarac, T. B. (2009). Aras,tırma-Gelis,tirme Harcamalarının Ekonomik Büyüme Üzerindeki Etkisi: Panel Veri Analizi [The Effect of Research-Development Expenditures on Economic Growth: A panel data]. EconAnadolu 2009: Anadolu International Conference in Economics, Eskis, ehir, Turkey.

Schumpeter, J. A. (1970). Capitalism, Socialism and Democracy. London: Unwin University Books.

Segerstrom, P. S. (2000). The long-run growth effects of R\&D subsidies. Journal of Economic Growth 5(3), 277-305. https://doi.org/10.1023/A:1009881717993

Şimşek, M., \& Behdioğlu, S. (2006). Araştırma-geliştirme (AR-GE) faaliyetlerinin Türkiye-OECD ülkelerinde kümeleme analizi ile incelenmesi ve ekonomik büyümedeki önemi. İktisat İsletme ve Finans, 21(245), 123-137. https://doi.org/10.3848/iif.2006.245.5144

Sylwester, K. (2001). R\&D and economic growth. Knowledge, Technology, \& Policy, 13(4), 71-84. https://doi.org/10.1007/BF02693991

Taban, S., Şengür, M. (2013). Türkiye'de Ar-Ge ve Ekonomik Büyüme. AIBBÜ Sosyal Bilimler Enstitüsü Dergisi, 14(1), 355-376.

Ulku, H. (2004). R\&D, Innovation, and Economic Growth: An Empirical Analysis. IMF Working Paper, No.04/185. https://doi.org/10.5089/9781451859447.001

Verbic, M., Majcen, B., Ivanova, O., \& Cok, M. (2011). R\&D and Economic Growth in Slovenia: A Dynamic General Equilibrium Approach with Endogenous Growth. Panoeconomicus, 1, 67-89. https://doi.org/10.2298/PAN1101067V

Yanyun, Z., \& Mingqian, Z. (2004). R\&D and Economic Growth-Panel Data Analysis in ASEAN+3 Countries. The Center for Applied Statistics, Renmin University of China. http://faculty.washington.edu/karyiu/confer/seoul04/seoul04-papers.htm (Access Date: 22.09.2015)

Yaylalı, M., Akan, Y., \& Iş̧1k, C. (2010). Türkiye'de AR\&GE Yatırım Harcamaları ve Ekonomik Büyüme Arasındaki Eş-bütünleşme ve Nedensellik İlişkisi: 1990-2009 [ Cointegration and Casuality Between R\&D 
Investment Expenditures and Economic Growth in Turkey]. Bilgi Ekonomisi ve Yönetimi Dergisi, V(II), 13-26.

Zachariadis, M. (2004). R\&D-induced growth in the OECD. Review of Development Economics, 8(3), $423-439$. https://doi.org/10.1111/j.1467-9361.2004.00243.x

\section{Copyrights}

Copyright for this article is retained by the author(s), with first publication rights granted to the journal.

This is an open-access article distributed under the terms and conditions of the Creative Commons Attribution license (http://creativecommons.org/licenses/by/4.0/). 